\title{
Synthesis of $\mathrm{Ag} / \mathrm{AgCl}$ Nanoparticles Immobilized on $\mathrm{CoFe}_{2} \mathrm{O}_{4}$ Fibers and Their Photocatalytic Degradation for Methyl Orange
}

\author{
Li Ziyu, Jia Zhigang, Li Wenwen, Liu Jianhong, Jiang Shan, Li Shengbiao, \\ Zhu Rongsun
}

Anhui University of Technology, Ma'anshan 243002, China

\begin{abstract}
Ag} / \mathrm{AgCl}$ nanoparticles were immobilized onto the as-prepared $\mathrm{CoFe}_{2} \mathrm{O}_{4}$ fibers by a facile synthesis method. The amount of $\mathrm{Ag} / \mathrm{AgCl}$ nanoparticles immobilized onto $\mathrm{CoFe}_{2} \mathrm{O}_{4}$ fibers could be tuned. The as-synthesized $\mathrm{Ag} / \mathrm{AgCl} @ \mathrm{CoFe}_{2} \mathrm{O}_{4}$ composite fibers were characterized by XRD, FESEM and EM, and employed to degradate MO (methyl orange) dye in wastewater under visible light. The results show that AAC-4 fiber exhibits higher efficiency for the degradation of the MO dye under visible light illumination than other $\mathrm{Ag} / \mathrm{AgCl} @ \mathrm{CoFe}_{2} \mathrm{O}_{4}$ composite fibers or pure $\mathrm{Ag} / \mathrm{AgCl}$ sample, and the decolorizing efficiency of $\mathrm{MO}$ can research 98.2\%. The immobilization of $\mathrm{Ag} / \mathrm{AgCl}$ nanoparticles onto $\mathrm{CoFe}_{2} \mathrm{O}_{4}$ fiber promotes the enhancement of photocatalytic efficiency and stability.
\end{abstract}

Key words: immobilization; photocatalytic activity; methyl orange; degradation

With the development of modern industry, water pollution caused by the organic dyes poses severe challenges to the ecosystem and human health due to the organic dyes of toxicity and non-biodegradability ${ }^{[1]}$. In the past several years, many efforts have been done to find simple and effective methods to eliminate dye pollutant from wastewater. Traditional chemical and biological-based processes are used for wastewater treatment but have several disadvantages ${ }^{[2-4]}$.

Light photocatalytic degradation has attracted considerable attention to solve the aromatically structured organic dyes because of potential improvements in simplicity and cost-effectiveness ${ }^{[5]}$. The irradiation of photocatalytic semiconductor materials with specific wavelength of light results in the formation of electron-hole couples which promote reduction and oxidation reactions. This unique property of semiconductors has been used to develop environmental remediation technologies for wastewater treatment ${ }^{[6-8]}$.

In the various semiconductors, titanium dioxide $\left(\mathrm{TiO}_{2}\right)$ is a sufficient available and non-toxic semiconductor. The photocatalyst design based on $\mathrm{TiO}_{2}$ was widely investigated However, the large band gap and low electron-hole separation efficiency of $\mathrm{TiO}_{2}$ in visible light spectra restrict its application ${ }^{[9]}$. Silver/silver halide $(\mathrm{Ag} / \mathrm{Ag} X)$ possesses high efficiency for visible light utilization because of the surface plasmon resonance of metallic Ag and its synergistic effect with the photosensitive characteristic of $\mathrm{AgX}$. Among the various plasmonic photocatalysts, $\mathrm{Ag} / \mathrm{AgCl}$-based composites have received considerable attention owing to the outstanding photocatalytic performance and excellent stability ${ }^{[10]}$.

However, it is difficult to recover ultrafine $\mathrm{Ag} / \mathrm{AgCl}$ powder from the aqueous dispersion after the photodegradation process. Immobilization of $\mathrm{Ag} / \mathrm{AgCl}$ particles on substrates is an effective method to resolve

Received date: December 25, 2016

Foundation item: National Natural Science Foundation of China (20907001); Training Programs of Innovation for Undergraduates of Anhui University of Technology (2015019)

Corresponding author: Jia Zhigang, Ph. D., Professor, School of Chemistry and Chemical Engineering, Anhui University of Technology, Ma'anshan 243002, P. R. China, Tel: 0086-555-2311807, E-mail: zjchemyue@126.com 
these problems ${ }^{[11]}$. The application of magnetic carrier in environmental field is one of several new and innovative methods that have received considerable attention in recent years ${ }^{[12-14]}$. Compared with conventional separation, the advantages of magnetic carrier come from its speed, accuracy, and simplicity. Magnetic particles can be used as carrier for various active materials and the active materials can be randomly separated from the solution by a simple magnetic process. In the present work, $\mathrm{Ag} / \mathrm{AgCl}$ nanoparticles were immobilized onto $\mathrm{CoFe}_{2} \mathrm{O}_{4}$ fibers and their photocatalysis degradation for $\mathrm{MO}$ was investigated in detail.

\section{Experiment}

Silver nitrate, cobalt sulfate heptahydrate, iron (II) sulfate heptahydrate, oxalic acid, methyl orange (MO) and sodium chloride were of analytical grade and used as received. Deionized water was used as the solvent for all of the solutions or dispersions.

$\mathrm{CoFe}_{2} \mathrm{O}_{4}$ fibers were used as carrier of activated photocatalytic materials. $\mathrm{CoFe}_{2} \mathrm{O}_{4}$ fibers were firstly synthesized according to our previous reports ${ }^{[15]}$. Typically, 2 mmol $\mathrm{CoSO}_{4} \cdot 7 \mathrm{H}_{2} \mathrm{O}$ and $4 \mathrm{mmol} \mathrm{FeSO}_{4} \cdot 7 \mathrm{H}_{2} \mathrm{O}$ were dissolved into $80 \mathrm{~mL}$ ethylene glycol (EG)/water (W) solvent with the volume ratio of $V_{\mathrm{EG}} / V_{\mathrm{W}}=3: 1$. Then, $6 \mathrm{mmol} \mathrm{H}_{2} \mathrm{C}_{2} \mathrm{O}_{4} \cdot 2 \mathrm{H}_{2} \mathrm{O}$ were added into the above-mentioned solvent. Subsequently, the mixture was transferred to a $100 \mathrm{~mL}$ Teflon-lined stainless steel autoclave and kept at $120{ }^{\circ} \mathrm{C}$ for $10 \mathrm{~h}$. After cooling to room temperature, the final products were collected by washing with deionized water and three times with ethanol, and then dried at $100{ }^{\circ} \mathrm{C}$. The obtained product was calcined at $500{ }^{\circ} \mathrm{C}$ for $2 \mathrm{~h}$ to obtain $\mathrm{CoFe}_{2} \mathrm{O}_{4}$ fibers.

The as-prepared $\mathrm{CoFe}_{2} \mathrm{O}_{4}$ fibers were employed as carrier of nanosized $\mathrm{Ag} / \mathrm{AgCl}$ composite. The specific synthesis process can be described as follows: $50 \mathrm{mg} \mathrm{CoFe}{ }_{2} \mathrm{O}_{4}$ fibers were added into $50 \mathrm{~mL}$ PVP solution (40 wt $\%$ ). Then, $\mathrm{CoFe}_{2} \mathrm{O}_{4}$ fibers were separated by a magnet, washed several times and redispersed into $40 \mathrm{~mL} \mathrm{AgNO}_{3}$ solution. $\mathrm{NaCl}$ solution $(40 \mathrm{~mL})$ with the same concentration was added into $\mathrm{AgNO}_{3}$ solution drop by drop under vigorous stirring in $40 \mathrm{~min}$. After the addition was finished, the mixture was exposed to $125 \mathrm{~W}$ UV light with the distance of $15 \mathrm{~cm}$ for $10 \mathrm{~min}$. Finally, the sample was magnetically separated from the solution and dried for the further use. The concentration of solution was set as $1.25,2.5,5$ and 7.5 $\mathrm{mmol} / \mathrm{L}$, respectively. Accordingly, the as-prepared samples were named AAC-1, AAC-2, AAC-3 and AAC-4, respectively. Pure $\mathrm{Ag} / \mathrm{AgCl}$ sample and $\mathrm{CoFe}_{2} \mathrm{O}_{4}$ fibers named as AAC-0 were also prepared.

The phase purity and crystal structure of the obtained samples were examined by X-ray diffraction (XRD, Bruker D8 Advance $\mathrm{X}$-ray diffractometer) with $\mathrm{Cu}-\mathrm{K} \alpha$ radiation $(\lambda=0.15406 \mathrm{~nm})$. The morphologies of the resulting samples were characterized by a field emission scanning electron microscopy (Nova NanoSEM 450, Holland) and electron microscope (LI00 S600T, Germany).

The photocatalytic activities of AAC composites were evaluated with the catalytic degradation of MO under irradiation using a $500 \mathrm{~W}$ xenon lamp equipped with a 400 $\mathrm{nm}$ cut-off filter. For each test, $0.05 \mathrm{~g}$ catalyst powder was added into $100 \mathrm{~mL} 10 \mathrm{mg} / \mathrm{L} \mathrm{MO}$ solution. The test solutions were stirred in the dark for $30 \mathrm{~min}$ before irradiated under the visible light. During the irradiation, $3 \mathrm{~mL}$ sample of the reaction suspension was taken every $3 \mathrm{~min}$. The supernatant was collected and analyzed on the visible spectrophotometer. Photocatalytic degradations of MO in the dark in the presence of the photocatalyst and under visible light irradiation in the absence of the photocatalyst were also used as negative controls.

\section{Results and Discussion}

The phase composition of the magnetic carrier, typical carrier modified by $\mathrm{AgCl}$ and $\mathrm{AAC}-4$ photocatalyst was determined with XRD as shown in Fig.1. The diffraction peaks of $\mathrm{CoFe}_{2} \mathrm{O}_{4}$ corresponding to $2 \theta$ values of $30.10^{\circ}$, $35.72^{\circ}, 42.98^{\circ}, 56.79^{\circ}$, and $62.41^{\circ}$ are confirmed as the planes (220), (311), (400), (511), and (440), respectively. The pattern can be identified as spinel $\mathrm{CoFe}_{2} \mathrm{O}_{4}$ with the lattice parameters of a cubic structure (space group $\mathrm{Fd} 3 \mathrm{~m}$, JCPDS card No. 82-1049). The peaks of $\mathrm{AgCl} @ \mathrm{CoFe}_{2} \mathrm{O}_{4}$ at $2 \theta=27.8^{\circ}, 32.2^{\circ}, 46.2^{\circ}, 54.8^{\circ}$ and $57.5^{\circ}$ are attributed to (111), (200), (220), (311) and (222) crystal planes of $\mathrm{AgCl}$ (JCPDS No. 85-1355) besides the characterization peaks of $\mathrm{CoFe}_{2} \mathrm{O}_{4}$, indicating the formation of $\mathrm{AgCl} @ \mathrm{CoFe}_{2} \mathrm{O}_{4}$ composite. The peaks of $\mathrm{Ag} / \mathrm{AgCl} @ \mathrm{CoFe}_{2} \mathrm{O}_{4}$ at $2 \theta=38.1^{\circ}$ can be ascribed to the metallic Ag (JCPDS No. 87-717) and the weak peak intensity can be ascribed to the minor deposition amount under light illumination ${ }^{[16]}$. No characteristic peaks attributing to impurities or other phases are detected besides the characterization peaks of $\mathrm{CoFe}_{2} \mathrm{O}_{4}$ and $\mathrm{AgCl}$, demonstrating that the obtained product is composed of metallic $\mathrm{Ag}, \mathrm{AgCl}$ and $\mathrm{CoFe}_{2} \mathrm{O}_{4}$ phase.

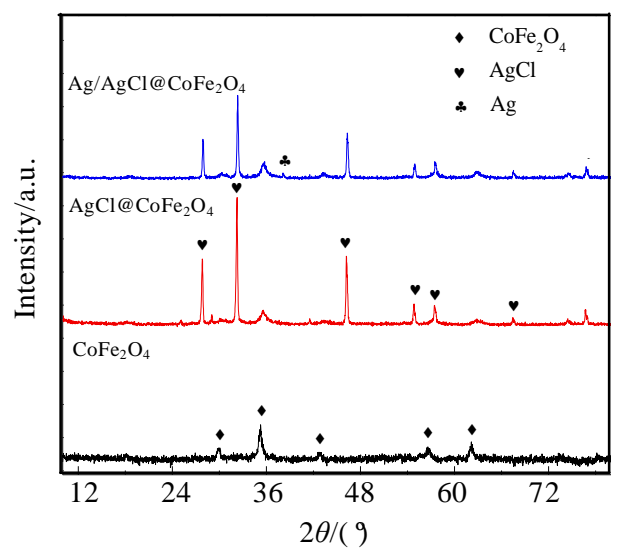

Fig.1 XRD patterns of the as-prepared samples 
SEM and EM images of AAC-0 $\left(\mathrm{CoFe}_{2} \mathrm{O}_{4}\right.$ fiber $)$ and AAC-4 fibers are illustrated in Fig.2. The as-prepared $\mathrm{CoFe}_{2} \mathrm{O}_{4}$ carrier is fiber-like morphology with high aspect ratio as shown in Fig.2a. Fig.2b is the SEM image of AAC-4 sample. It is easy to observe that plenty of nanoparticles adhere to the surface of $\mathrm{CoFe}_{2} \mathrm{O}_{4}$ carrier. The change can also be found through the EM images of $\mathrm{CoFe}_{2} \mathrm{O}_{4}$ fiber and AAC-4 sample as shown in Fig.2c and
$2 \mathrm{~d}$. The surface of AAC-4 sample becomes rough while the surface of $\mathrm{CoFe}_{2} \mathrm{O}_{4}$ fiber is relatively smooth because of the attachment of $\mathrm{Ag} / \mathrm{AgCl}$ nanoparticles.

The formation process of $\mathrm{Ag} / \mathrm{AgCl} @ \mathrm{CoFe}_{2} \mathrm{O}_{4}$ fiber can be illustrated in Fig.3. The surface of $\mathrm{CoFe}_{2} \mathrm{O}_{4}$ fiber is firstly coated with PVP molecules. $\mathrm{Ag}^{+}$and PVP chains form a $\mathrm{Ag}^{+}$-PVP complex in liquid solutions, and the $\mathrm{Ag}^{+}$ ions uniformly disperse in the voids of PVP chains ${ }^{[17]}$.

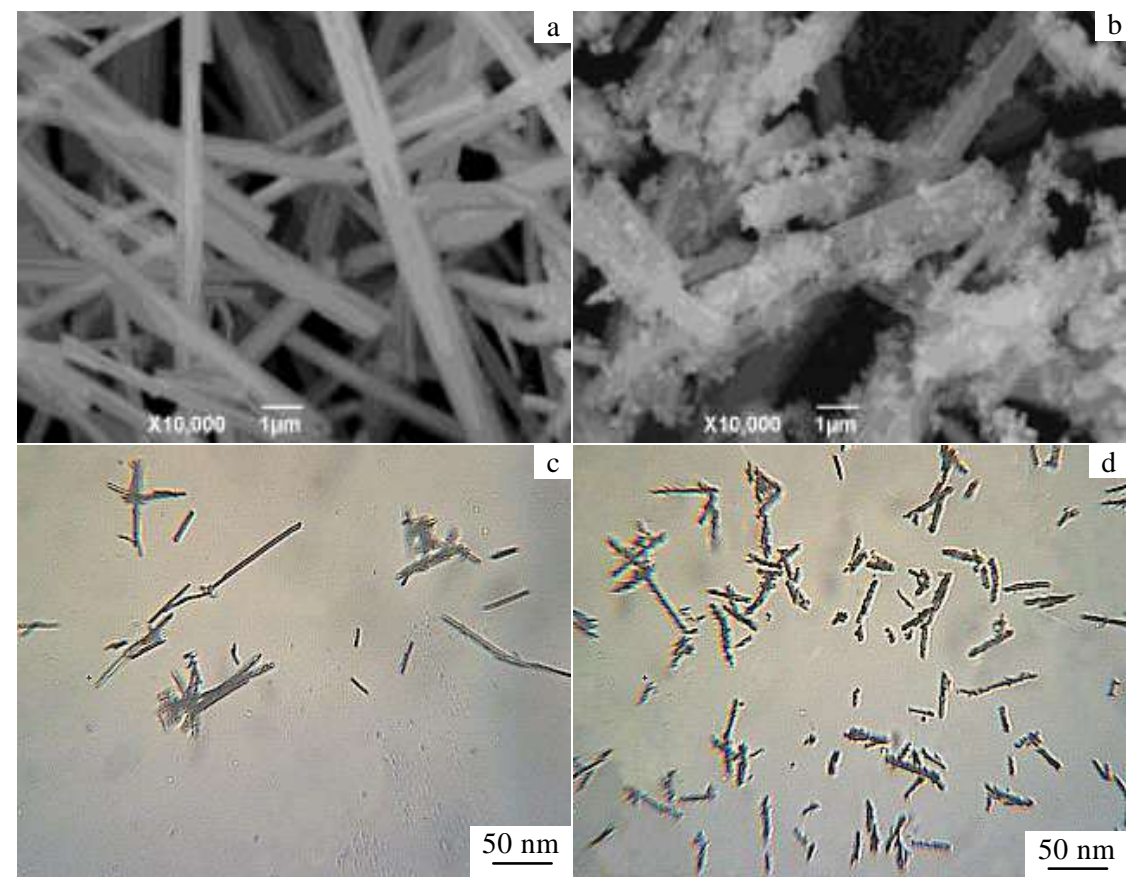

Fig.2 SEM (a, b) and EM (c, d) images of $\mathrm{CoFe}_{2} \mathrm{O}_{4}(\mathrm{AAC}-0)(\mathrm{a}, \mathrm{c})$ and $\mathrm{Ag} / \mathrm{AgCl} @ \mathrm{CoFe}_{2} \mathrm{O}_{4}(\mathrm{AAC}-4)(\mathrm{b}, \mathrm{d})$

$\mathrm{CoFe}_{2} \mathrm{O}_{4}$ fiber

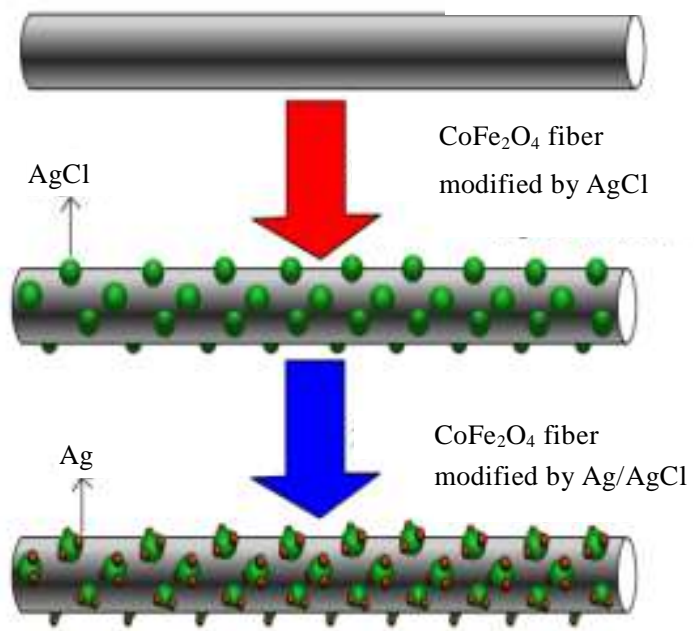

Fig.3 Schematic illustration of $\mathrm{CoFe}_{2} \mathrm{O}_{4}$ fiber modified by $\mathrm{Ag} / \mathrm{AgCl}$ nanoparticles
Then, PVP molecule induces the nucleation and crystallization of $\mathrm{AgCl}$ nanoparticles in the solution and the $\mathrm{AgCl}$ nanoparticles are in-situ formed and attach on the surface of $\mathrm{CoFe}_{2} \mathrm{O}_{4}$ fiber. Subsequently, $\mathrm{AgCl}$ nanoparticles onto $\mathrm{CoFe}_{2} \mathrm{O}_{4}$ fiber are partially reduced to metallic Ag to form $\mathrm{Ag} / \mathrm{AgCl}$ nanoparticles under the irradiation of $\mathrm{UV}$ light.

The photocatalytic activities of the as-prepared $\mathrm{Ag} / \mathrm{AgCl} @ \mathrm{CoFe}_{2} \mathrm{O}_{4}$ fibers were examined by the degradation of $\mathrm{MO}$ in aqueous solution under visible light irradiation, and the results are shown in Fig.4. The suspension was magnetically stirred for $60 \mathrm{~min}$ in the dark to achieve the adsorption equilibrium of the $\mathrm{MO}$ on the photocatalyst powder before illumination. Control experiments in the absence of visible light irradiation indicate that AAC sample has lower capacity towards the adsorption of MO (about $6 \%$ after $60 \mathrm{~min}$ ). The direct photolysis of $\mathrm{MO}$ in the absence of photocatalyst is negligible within the test period. In the presence of AAC photocatalyst and light, the degradation ratio of $\mathrm{MO}$ increases with the increasing irradiation time. Moreover, 


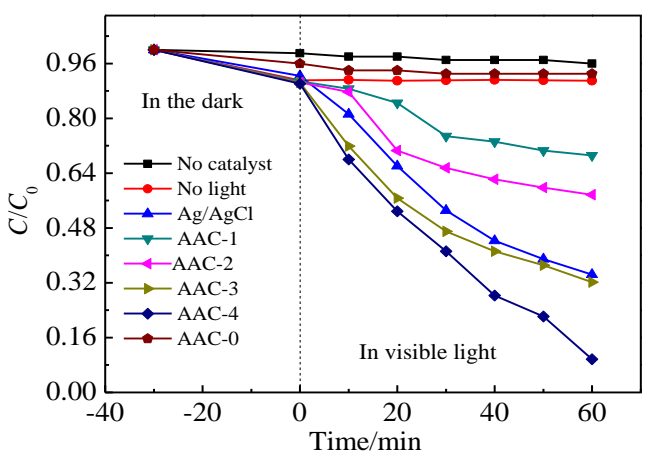

Fig.4 Degradation curves of methyl orange (MO) solution using $\mathrm{Ag} / \mathrm{AgCl} @ \mathrm{CoFe}_{2} \mathrm{O}_{4}$ fibers with different packages

photocatalytic activity of AAC is gradually enhanced with the increase of $\mathrm{Ag} / \mathrm{AgCl}$ loaded onto $\mathrm{CoFe}_{2} \mathrm{O}_{4}$ fiber. The photocatalytic activity trend follows the order: $\mathrm{AAC}-1<\mathrm{AAC}-2<\mathrm{Ag} / \mathrm{AgCl} \leq \mathrm{AAC}-3<\mathrm{AAC}-4$. The content of $\mathrm{Ag} / \mathrm{AgCl}$ in $\mathrm{AAC}-3$ and $\mathrm{AAC}-4$ sample is obviously lower than that of pure $\mathrm{Ag} / \mathrm{AgCl}$ and the photocatalysis efficiency of AAC-3 and AAC-4 sample is higher than that of pure $\mathrm{Ag} / \mathrm{AgCl}$, indicating $\mathrm{Ag} / \mathrm{AgCl}$ immobilized onto $\mathrm{CoFe}_{2} \mathrm{O}_{4}$ fiber shows higher photocatalytic activity. It is also reported that $\mathrm{CoFe}_{2} \mathrm{O}_{4}$ can be used as photocatalyst for the degradation of pollutant ${ }^{[18]}$. However, in our work, the as-prepared $\mathrm{CoFe}_{2} \mathrm{O}_{4}$ fiber (AAC-0) do not reveal any clear photocatalytic activity under the illumination of visible light and the minor reduction of $\mathrm{MO}$ in solution can be ascribed to the adsorption. Therefore, the species of $\mathrm{Ag} / \mathrm{AgCl}$ in the composite are proved to be responsible for the degradation of MO.

Fig. 5 shows the variation of UV-vis absorption spectrum of MO degradation. The maximum absorption band MO dye is located at $463 \mathrm{~nm}$. The intensity of the absorption peak gradually decreases with the time increasing. Simultaneously, it is obviously observed that the maximum absorption peak of MO is red-shifted, which is attributed to the step-by-step hydroxylation process ${ }^{[19]} \cdot 98.2 \%$ of MO is mineralized after irradiation for $60 \mathrm{~min}$, indicating $\mathrm{MO}$ can be degraded by AAC-4 photocatalyst under visible light irradiation.

To test the stability of photocatalyst, AAC-4 photocatalyst was collected after photodegradation experiments of MO. As shown in Fig.6a, the degradation rate becomes lower with the increasing number of recycle. However, AAC-4 still maintains $75 \%$ degradation rate after five recycles for $\mathrm{MO}$, indicating the good photocatalytic stability. After every cycle, AAC-4 can be magnetically separated from the solution by a magnet as demonstrated by Fig.6b.
A series of comparative tests were further conducted to determine the reactive active species generated during the irradiation of AAC-4 photocatalyst. During the experiments, EDTA was used as holes radical scavenger and methanol or $\mathrm{NaHCO}_{3}$ as hydroxyl radical scavenger. As shown in Fig.7, the addition of EDTA significantly reduces the photocatalytic activity of AAC-4 photocatalyst and only $15 \%$ of $\mathrm{MO}$ can be degradated. However, it can be observed that methanol and $\mathrm{NaHCO}_{3}$ have a relatively little influence for photocatalytic activity, and about $65 \%$ and $60 \%$ of MO have been degradated in $50 \mathrm{~min}$. These results indicate that hydroxyl (HO.) specie participates in the photocatalytic mechanism but it is not the major oxidation species in the process due to the higher reduction of the photodegradation rate when a hole scavenger is added. Photogenerated holes $\left(\mathrm{h}^{+}\right)$on the catalyst surface must be the major active species participating in the degradation process.

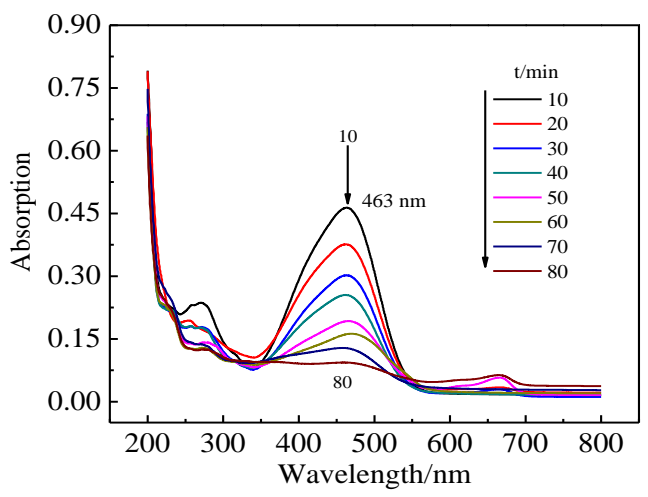

Fig.5 Time-dependent UV-vis absorption spectra of MO solution in the presence of AAC-4 photocatalyst

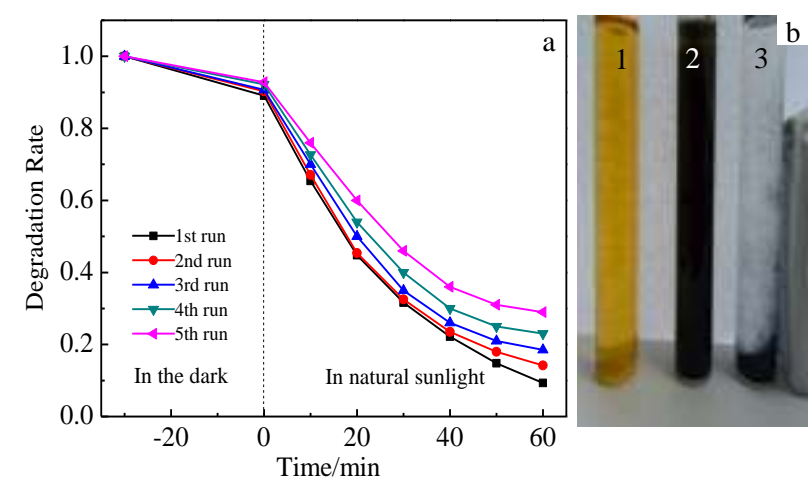

Fig.6 Photodegradation performance of AAC-4 composite over five consecutive cycles (a); magnetic separation photo of photocatalyst (1-MO solution; 2-mixture of MO and photocatalyst in solution; 3-separation of photocatalyst from the MO solution after degradation) (b) 


\section{Conclusion}

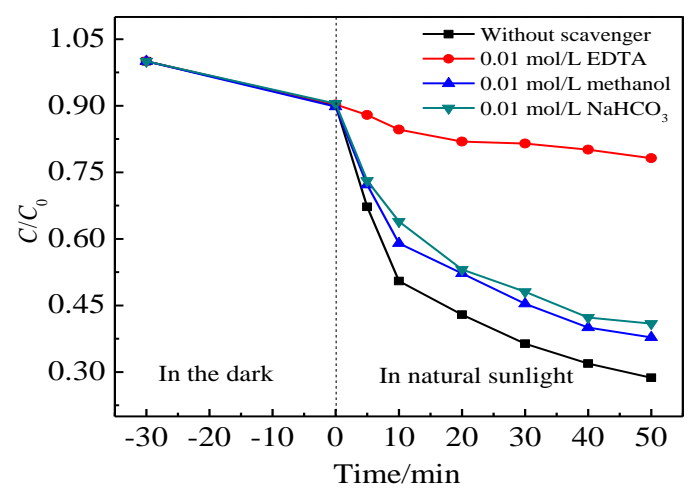

Fig.7 Effect of scavengers on degradation of methyl orange by $\mathrm{Ag} / \mathrm{AgCl} @ \mathrm{CoFe}_{2} \mathrm{O}_{4}$ fiber

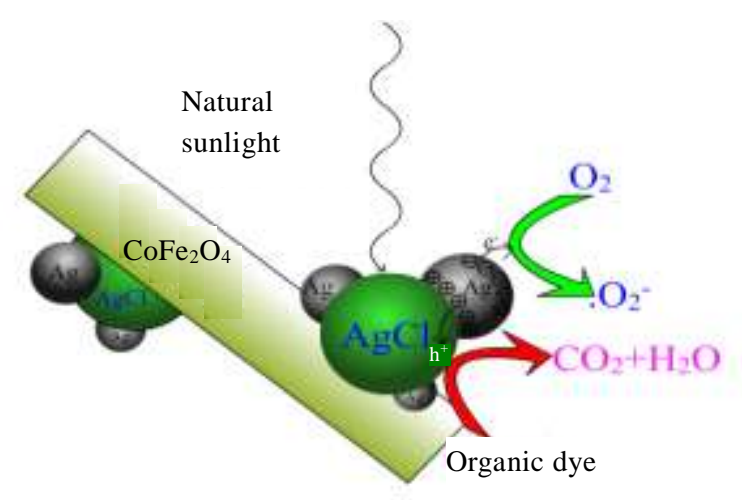

Fig.8 Schematic illustration of the photocatalytic degradation mechanism of organic dyes using the AAC crystals under natural light irradiation

Based on the above results, the photocatalytic degradation mechanism of MO using the AAC crystals under natural light irradiation can be deduced as Fig.8. Under natural light irradiation, the metallic $\mathrm{Ag}$ of the $\mathrm{Ag} @ \mathrm{AgCl}$ composite produces photogenerated electron-holes. The electrons move to the Ag nanoparticles, whereas holes move to the $\mathrm{AgCl}$. The generated electrons are prevented from being transferred to $\mathrm{Ag}^{+}$in $\mathrm{AgCl}^{[20]}$, but are instead transferred to molecular oxygen to form active species such as superoxide ${ }^{[21]}$. At the same time, the holes generated could also oxidize water to produce hydroxyl radicals, or directly oxidize $\mathrm{Cl}^{-}$ions into $\mathrm{Cl}_{0}^{[22]}$. The oxidized species may interact with dye molecular to degrade into $\mathrm{CO}_{2}$ and $\mathrm{H}_{2} \mathrm{O}$. In addition, well-dispersed $\mathrm{Ag} / \mathrm{AgCl}$ nanoparticles onto the surface of $\mathrm{CoFe}_{2} \mathrm{O}_{4}$ fiber (AAC-4) possess more active sites and show higher photocatalytic activity than pure $\mathrm{Ag} / \mathrm{AgCl}$.
1) The as-synthesized AAC-4 fiber exhibits high efficiency for catalyzing the decomposition of the MO dye under visible light illumination as well as high stability and recyclability.

2) The enhancement of photocatalytic efficiency can be ascribed to the immobilization of $\mathrm{Ag} / \mathrm{AgCl}$ nanoparticles onto $\mathrm{CoFe}_{2} \mathrm{O}_{4}$ fiber, and more active sites can be employed for the photocatalytic degradation.

3) The photocatalyst can be recycled from solution by magnetical separation due to the magnetic property of $\mathrm{CoFe}_{2} \mathrm{O}_{4}$ fiber. Therefore, the as-prepared AAC-4 materials with high photocatalytic activity could be promising to eliminate the dye pollutant from waste water.

\section{References}

1 Oladipo A A, Gazi M, Yilmaz E. Chemical Engineering Research and Design [J], 2015, 104: 264

2 Kumar V, Gohain M, Som S et al. Physica B: Condensed Matter [J], 2016, 480: 36

3 Volikov A B, Ponomarenko S A, Konstantinov A I et al. Chemosphere [J], 2016, 145: 83

4 Yagub M T, Sen T K, Afroze S et al. Advanced Colloid Interface Scence [J], 2014, 209: 172

5 Chen F J, Cao Y L, Jia D Z et al. Dyes and Pigments[J], 2015, 120: 8

6 Chowdhury S, Balasubramanian R. Applied Catalysis B: Environmental[J], 2014, 160-161: 307

7 Duta A, Visa M. Journal of Photochemistry and Photobiology A: Chemistry[J], 2015, 306: 21

8 Qamar M, Gondal M A, Hayat K et al. Journal of Hazardous Material[J], 2009, 170(2-3): 584

9 Vaiano V, Sacco O, Sannino D et al. Applied Catalysis B: Environmental[J], 2015, 170-171: 153

$10 \mathrm{Li}$ W, Ma Z Y, Bai G Q et al. Applied Catalysis B: Environmental[J], 2015, 174-175: 43

11 McEvoy J G, Cui W Q, Zhang Z S. Applied Catalysis B: Environmental[J], 2014, 144: 702

12 Lu L, Li J, Yu J et al. Chemical Engineering Journal[J], 2016, 283: 524

13 Mahmoodi N M. Journal of Industrial and Engineering Chemistry[J], 2015, 27: 251

14 Hosseinzadeh H, Mohammadi S. Carbohydrate Polymers [J], 2015, 134: 213

15 Jia Z G, Ren D P, Zhu R S. Materials Letters[J], 2012, 66(1): 128

16 Yu L Q, Zhang Y P, Zhi Q Q et al. Sensors and Actuators B: Chemical[J], 2015, 211: 111

17 Chen D L, Liu M N, Chen Q Q et al. Applied Catalysis B: Environmental[J], 2014, 144: 394

18 Zhang D F, Pu X P, Gao Y Y et al. Materials Letters[J], 2013, 113: 179

19 Lam S M, Sin J C, Abdullah A Z et al. Separation and 
Purification Technology[J], 2014, 132: 378

20 Zhou Z D, Peng X W, Zhong L X et al. Carbohydrate

Polymers[J], 2016, 136: 322
21 Daupor H, Wongnawa S. Appl Catal A: Gen[J], 2014, 473: 59

22 Wang P, Ming T S, Wang G H et al. Journal of Molecular Catalysis A: Chemical[J], 2014, 381: 114

\title{
铁酸钴纤维负载银/氯化银纳米粒子的合成及其对甲基橙的光催化降解
}

\author{
李紫宇, 贾志刚, 李雯雯, 刘建红, 江 姗, 李圣标, 诸荣孙 \\ (安徽工业大学, 安徽 马鞍山 243002)
}

\begin{abstract}
摘 要: 通过温和的湿化学合成法将 $\mathrm{Ag} / \mathrm{AgCl}$ 纳米粒子固载于 $\mathrm{CoFe}_{2} \mathrm{O}_{4}$ 纤维表面, 固载银/氯化银纳米粒子的量可控。利用 X射线衍射, 扫描电子显微镜和电子显微镜等技术对制备的 $\mathrm{Ag} / \mathrm{AgCl} @ \mathrm{CoFe}_{2} \mathrm{O}_{4}$ 组成、形貌等进行了表征。以甲基橙的降解脱色为模型反应, 考察了 $\mathrm{Ag} / \mathrm{AgCl}$ 纳米粒子的不同负载量对催化性能的影响。实验结果表明: AAC-4型固载纤维光催化剂展示出比其它类型固载光催化剂以及单 纯 $\mathrm{Ag} / \mathrm{AgCl}$ 纳米粒子更高的光催化性能, 可使甲基橙溶液 $60 \mathrm{~min}$ 的脱色率达 $98.2 \%$, 且 $\mathrm{Ag} / \mathrm{AgCl}$ 纳米粒子在 $\mathrm{CoFe}_{2} \mathrm{O}_{4}$ 纤维表面的固载促进 了光催化剂催化效率和催化稳定性的提升。
\end{abstract}

关键词: 固载; 光催化活性; 甲基橙; 降解

作者简介: 李紫宇, 男, 1992 年生, 硕士, 安徽工业大学化学与化工学院, 安徽 马鞍山 243002, 电话: 0555-2311807, E-mail: zjchemyue@126.com 